Check for updates

Cite this: RSC Adv., 2019, 9, 29293

Received 5th June 2019

Accepted 11th September 2019

DOI: $10.1039 / c 9 r a 04246 f$

rsc.li/rsc-advances

\section{Biosynthesis of silver nanoparticles using endophytic bacteria and their role in inhibition of rice pathogenic bacteria and plant growth promotion}

\author{
Ezzeldin Ibrahim, ${ }^{\text {ab }}$ Hatem Fouad, ${ }^{\text {cd }}$ Muchen Zhang, ${ }^{a}$ Yang Zhang, (D) *a Wen Qiu, ${ }^{a}$ \\ Chengqi Yan, ${ }^{e}$ Bin $\mathrm{Li}^{\mathrm{a}}{ }^{\mathrm{J}}$ Jianchu $\mathrm{Mo}^{\mathrm{c}}$ and Jianping Chen ${ }^{\star \mathrm{e}}$
}

The biosynthesis of silver nanoparticles (AgNPs) through the use of endophytic bacteria is a safe replacement for the chemical method. The study aimed to synthesize AgNPs using endophytic bacterium Bacillus siamensis strain C1, which was isolated from the medicinal plant Coriandrum sativum. The synthesized AgNPs with the size of 25 to $50 \mathrm{~nm}$ were further confirmed and characterized by UV-visible spectroscopy, Fourier transform infrared spectroscopy, X-ray diffraction, transmission electron microscopy and scanning electron microscopy with EDS profile. The synthesized AgNPs at $20 \mu \mathrm{g} \mathrm{mL} \mathrm{L}^{-1}$ showed a strong antibacterial effect against the pathogen of rice bacterial leaf blight and bacterial brown stripe, while an inhibition zone of 17.3 and $16.0 \mathrm{~mm}$ was observed for Xanthomonas oryzae pv. oryzae (Xoo) strain LND0005 and Acidovorax oryzae (Ao) strain RS-1, respectively. Furthermore, the synthesized AgNPs significantly inhibited bacterial growth, biofilm formation and swimming motility of Xoo strain LND0005 and Ao strain RS-1. In addition, the synthesized AgNPs significantly increased root length, shoot length, fresh weight and dry weight of rice seedlings compared to the control. Overall, this study suggests that AgNPs have the potential to protect rice plants from bacterial infection and plant growth promotion.

\section{Introduction}

Rice (Oryza sativa L), one of the most important staple food crops, is an essential food for more than $50 \%$ of the world population. ${ }^{1}$ One of the main obstacles to the production of rice is the frequent infection with bacterial diseases such as bacterial leaf blight and bacterial brown stripe, which are caused by Xanthomonas oryzae pv. oryzae (Xoo) and Acidovorax oryzae (Ao), respectively. The two main rice bacterial diseases have caused considerable losses in yield. ${ }^{1-5}$ The current control of rice bacterial leaf blight and bacterial brown stripe is mainly dependent on the use of bactericide. ${ }^{6-8}$ However, more and more attention has been paid to the risk of the conventional

\footnotetext{
${ }^{a}$ State Key Laboratory of Rice Biology, Ministry of Agriculture, Key Lab of Molecular Biology of Crop Pathogens and Insects, Institute of Biotechnology, College of Agricultural and Biotechnology, Zhejiang University, Hangzhou, 310058, PR China. E-mail: 0618151@zju.edu.cn

${ }^{b}$ Department of Vegetable Diseases Research, Plant Pathology Research Institute, Agriculture Research Centre, Giza, Egypt

'Ministry of Agriculture, Key Lab of Molecular Biology of Crop Pathogens and Insect Pests, Institute of Insect Sciences, College of Agricultural and Biotechnology, Zhejiang University, Hangzhou, 310058, PR China

${ }^{d}$ Department of Field Crop Pests, Plant Protection Research Institute, Agricultural Research Centre, Cairo, Egypt

Institute of Plant Virology, Ningbo University, Ningbo, 315211, China. E-mail: jpchen2001@126.com
}

chemical bactericides to the human and natural ecosystem. Therefore, it is very necessary to develop an alternative method to control the two main rice bacterial diseases.

Many studies have shown that nanoparticles that can be used to play an important role in the management of plant disease and promotion of plant growth. ${ }^{9}$ For example, metallic nanoparticles such as zinc oxide nanoparticles and MgO nanoflowers showed high antibacterial activity against bacterial leaf blight disease.,4 Furthermore, silver nanoparticles (AgNPs) showed strong inhibition on Gram-positive and Gram-negative bacteria. ${ }^{\mathbf{8 , 1 0 , 1 1}}$ Particularly, biological methods have been more and more applied in synthesize of the nanoparticles, which are more safe and eco-friendly compared to the traditional physical and chemical methods. .,4,11 $^{\text {, }}$

The purpose of this study is to biologically synthesize AgNPs using culture filtrate of endophytic bacteria isolated from the medicinal plants and characterize the synthesized AgNPs to plant growth promotion ability, and antibacterial activity against two main rice pathogenic bacteria.

\section{Materials and methods}

\subsection{Biosynthesis of silver nanoparticles}

The endophytic bacteria Bacillus siamensis (B. siamensis) strain C1 was isolated from medicinal health plant Coriandrum 
sativum (C. sativum), and then stored in the Institute of Biotechnology, College of Agriculture and Biotechnology, Zhejiang University. The synthesis of AgNPs was carried out according to the method by Fouad et al. ${ }^{\mathbf{1 1}}$ with slight modification. In brief, bacteria were grown in LB medium at $30^{\circ} \mathrm{C}$ for 2 days. After centrifugation for $10000 \mathrm{rpm}$ at $8 \mathrm{~min}$, a $10 \mathrm{~mL}$ of culture filtrates were mixed with $90 \mathrm{~mL}$ of $3 \mathrm{mM}$ aqueous silver nitrate $\left(\mathrm{AgNO}_{3}\right)$ in $250 \mathrm{~mL}$ flask and incubated at $30{ }^{\circ} \mathrm{C}$ for $24 \mathrm{~h}$. The positive synthetic of AgNPs was determined based on the color change to dark brown. After repeated centrifugation and wash with distilled water, the AgNPs samples were stored at $-80{ }^{\circ} \mathrm{C}$ for future use.

\subsection{UV-vis spectra analysis}

The formation of AgNPs was confirmed according to the method of Fouad et al. ${ }^{11}$ by UV-vis spectra analysis. The absorption was recorded by UV-visible spectrophotometer 2550 (Shimadzu, Japan) at a resolution of $1 \mathrm{~nm}$ in the wavelengths range $200-800 \mathrm{~nm}$.

\subsection{Transmission electron microscopic (TEM) observation}

The morphology of the biosynthesized AgNPs was determined according to the method of Ogunyemi et al. ${ }^{3}$ by TEM observation using a Transmission Electron Microscopy (JEM-1230, JEOL, Akishima, Japan). In brief, the sample was prepared with the copper coated grid for $24 \mathrm{~h}$ at room temperature to make a film of the sample. The excess liquid was discarded and kept in a grid box sequentially.

\subsection{Scanning electron microscopy (SEM) and energy dispersive spectrum (EDS) analysis}

The structural morphology of the biosynthesized AgNPs had been watched and recorded according to the method of Fouad et $a{ }^{11}$ by Scanning Electron Microscopy (TM-1000, Hitachi, Japan). The film obtained from the sample was fixed on a carbon-coated grid. The instrument was equipped with an energy dispersive spectrum (EDS) to ensure the presence of silver metal.

\subsection{Fourier transforms infrared spectroscopy (FTIR) analysis}

The spectral characterization of the biosynthesized AgNPs were recorded as described by Fouad et al. ${ }^{\mathbf{1 1}}$ by Fourier Transform Infrared Spectroscopy (FTIR spectrometer vector 22, Bruker, Germany) using the dried powder of the synthesized AgNPs, in the spectral range of $400-4000 \mathrm{~cm}^{-1}$ at room temperature.

\subsection{X-ray diffraction (XRD) analysis}

The XRD patterns of the biosynthesized AgNPs were analyzed as described by Fouad et al. ${ }^{\mathbf{1 1}}$ using XPert PRO diffractometer (Holland) with a detector voltage of $45 \mathrm{kV}$ and a current of 40 $\mathrm{mA}$ using $\mathrm{Cu} \mathrm{K} \alpha$ radiation. The recorded range of $2 \theta$ was $20-80^{\circ}$ with a scanning speed of $6^{\circ} \mathrm{min}^{-1}$.

\subsection{In vitro assay of antibacterial activity}

Using the agar well diffusion method the antibacterial activity of the bio-synthesized AgNPs against Xoo strain LND0005 (ref. 5) and Ao strain RS-1 (ref. 2) was carried out according to Ogunyemi et al. ${ }^{3}$ with slight modification. Briefly, bacteria were grown in LB broth and incubated at $30{ }^{\circ} \mathrm{C}$ for $24 \mathrm{~h}$. A $200 \mu \mathrm{L}$ bacterial suspension $\left(10^{8} \mathrm{CFU} \mathrm{mL}^{-1}\right)$ was mixed with $10 \mathrm{~mL}$ of LB agar medium in a Petri dish. After solidification of the medium, the plate was inoculated with $40 \mu \mathrm{L}$ of the $\mathrm{AgNO}_{3}$ and AgNPs at different concentration of 5, 10, 15 and $20 \mu \mathrm{g} \mathrm{mL}^{-1}$. After incubation at $30{ }^{\circ} \mathrm{C}$ for one day, the antibacterial activity was determined by measuring the diameter of the inhibitory zone. The experiment was repeated three times.

\subsection{Determination of minimum inhibitory concentration} (MIC)

The MIC of the bio-synthesized AgNPs against Xoo strain LND0005 and Ao strain RS-1 was determined in 96-well microtiter plates according to the method of Elshakh et al. ${ }^{12}$ by measuring the optical density at $600 \mathrm{~nm}$ using a Scanning Microplate Spectrophotometer (Thermo Fisher Scientific Inc., Waltham, MA, USA). In brief, bacteria were incubated in LB broth at $30{ }^{\circ} \mathrm{C}$ for $12 \mathrm{~h}$ and adjusted to $10^{8} \mathrm{CFU} \mathrm{mL}{ }^{-1}$. Wells were filled with $200 \mu \mathrm{L}$ LB solutions containing $10 \mu \mathrm{L}$ of bacterial culture and AgNPs with the final concentrations of 5, 10,15 and $20 \mu \mathrm{g} \mathrm{mL}^{-1}$. The microtiter plates were incubated at $30{ }^{\circ} \mathrm{C}$ for $48 \mathrm{~h}$. Wells filled with bacteria alone were served as a control.

\subsection{Effect of AgNPs on swimming motility}

Effect of the bio-synthesized AgNPs on the swimming motility of Xoo strain LND0005 and Ao strain RS-1 was carried out according to the method of Ogunyemi et al. ${ }^{3}$ Briefly, the overnight bacterial culture was inoculated on LB medium $(0.4 \%, \mathrm{w} /$ v) agar mixed with AgNPs of 5, 10, 15 and $20 \mu \mathrm{g} \mathrm{mL}{ }^{-1}$, and then incubated at $30^{\circ} \mathrm{C}$ for one day. Bacterial culture without AgNPs was served as a control. Swimming motility was determined by measuring the migration diameter of the bacterial colony.

\subsection{Effect of AgNPs on biofilm formation}

Effect of the bio-synthesized AgNPs on biofilm formation of Xoo strain LND0005 and Ao strain RS-1 was assayed in 96-well plates (Corning-Costar Corp., Corning, NY, USA) according to Nijland et $a l .{ }^{13}$ with slight modification. Briefly, wells were filled with $200 \mu \mathrm{L}$ LB broth containing $100 \mu \mathrm{L}$ overnight bacterial culture and AgNPs at different final concentrations of 5, 10, 15 and 20 $\mu \mathrm{g} \mathrm{mL}^{-1}$. Bacterial cultures without AgNPs were served as the control. Biofilm formation was recorded by measuring the optical density at $570 \mathrm{~nm}$ by a Scanning Microplate Spectrophotometer (Thermo Fisher Scientific Inc., Waltham, MA, USA).

\subsection{Effect of AgNPs on cell morphology}

Effect of the biosynthesized AgNPs on the morphology of bacterial cells was determined according to the method of Ogunyemi et al. ${ }^{3}$ by TEM observation using a Transmission 
Electron Microscopy (JEOL, Tokyo, Japan). Bacterial samples were prepared by centrifuging the overnight bacterial culture at a concentration of $10^{8} \mathrm{CFU} \mathrm{mL}^{-1}$, at $11000 \mathrm{~g}$ for $10 \mathrm{~min}$ and then re-suspending the cells in $10 \mu \mathrm{g} \mathrm{mL}{ }^{-1} \mathrm{AgNPs}$ at $30{ }^{\circ} \mathrm{C}$ for $2 \mathrm{~h}$.

\subsection{Effect of AgNPs on plant growth promotion}

Effect of the biosynthesized AgNPs on the growth of rice plants was assessed according to the method by Verma et al. ${ }^{\mathbf{1 4}}$ with slight modification. Briefly, following the disinfection with $4 \%$ sodium hypochlorite for $15 \mathrm{~min}$ and wash with distilled sterile water three times, seeds of rice cultivar cv. Xiang Liang 900 were incubated with bacteria $\left(10^{8} \mathrm{CFU} \mathrm{mL}{ }^{-1}\right)$, AgNPs $\left(10 \mu \mathrm{g} \mathrm{mL}^{-1}\right)$ alone, and both of them at $30{ }^{\circ} \mathrm{C}$ for $10 \mathrm{~h}$. The negative control was treated with distilled sterile water. After 12 days of sowing the seeds on $0.4 \%$ agarose plates, the root lengths, shoot lengths, fresh weight and dry weight were recorded.

\subsection{Statistical analysis}

All experiments were conducted using a complete randomized design. General linear model (GLM) procedure was used to check the significant differences among main treatments and individual comparisons between mean values were performed by using the least significant differences (LSD) test $(P<0.05)$. Data were subjected to analysis of variance (ANOVA) test by using the SPSS software package 16.0 version (SPSS Inc., Chicago, IL).

\section{Results and discussion}

\subsection{Characterization of the bio-synthesized AgNPs}

Result from this study indicated that the AgNPs was successfully bio-synthesized based on the change of color from light yellow to dark brown, which has widely been considered as an indicator for the synthesis of nanoparticles. Furthermore, there was a different absorption peak between the $\mathrm{AgNO}_{3}$ and the AgNPs. Indeed, a peak at $300 \mathrm{~nm}$ was observed for the $\mathrm{AgNO}_{3}$ alone. However, this peak disappeared in the AgNPs, and a new absorption peak of $409 \mathrm{~nm}$ appeared after incubation at $30{ }^{\circ} \mathrm{C}$ for $24 \mathrm{~h}$ (Fig. 1). In agreement with the result of this study, previous reports showed that peaks of UV absorption of AgNPs were mentioned to range from 400 to $450 \mathrm{~nm}$, where it was watched at 405, 410, 420, and $426 \mathrm{~nm}$ in different studies. ${ }^{\mathbf{1 1 , 1 5 - 1 7}}$

The results of TEM and SEM indicated that the biosynthesized AgNPs were spherical shape with the size from 25 to $50 \mathrm{~nm}$ with average $34 \pm 3$ (Fig. 2A and B), which are consistent with the previous reports. ${ }^{11,16,18}$ The results of EDS analysis shows the peak of silver, chlorine and sulfur elements to be 91.8, 7.5, and 0.7\%, respectively, in the biosynthesized AgNPs (Fig. 2C). In agreement with previous studies, the broad peak of silver ions was formed at $3 \mathrm{keV}$, which is a guide to the reduction of $\mathrm{Ag}^{+}$to $\mathrm{Ag}^{0}$ (Fig. 2C). ${ }^{11,19,20}$

The XRD analysis showed the diffraction peaks at $2 \theta$ values of $27.81^{\circ}, 32.34^{\circ}, 46.29^{\circ}, 57.47^{\circ}$, and $77.69^{\circ}$, corresponding to (101), (111), (200), (220), and (311) crystal planes, respectively, in the biosynthesized AgNPs (Fig. 3A). Similar results have

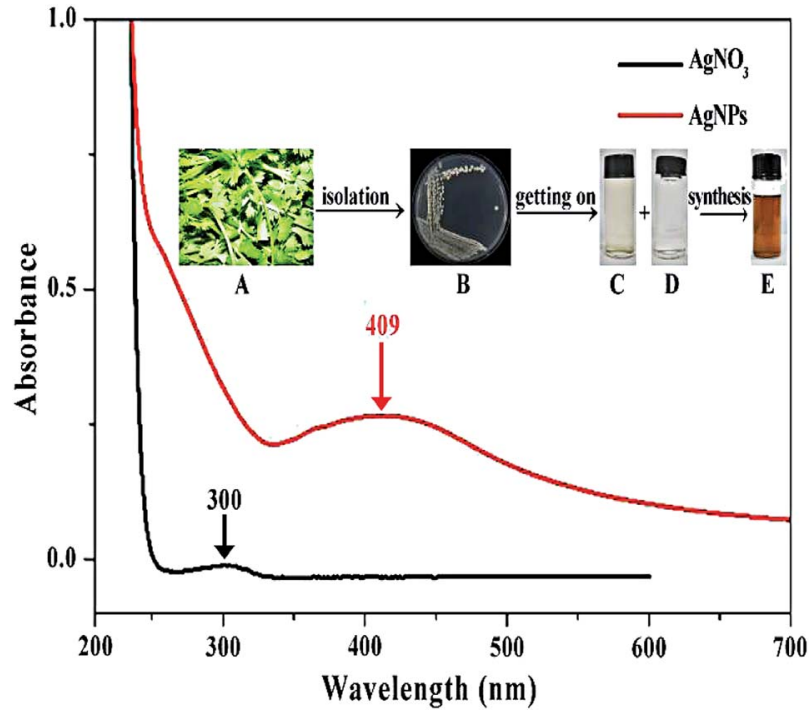

Fig. 1 Illustration of synthesis for the AgNPs. (A): C. sativum; (B): isolation of endophytic bacteria; (C) cell-free supernatant; (D): $\mathrm{AgNO}_{3}$; (E) the reduction of $\mathrm{Ag}^{+}$to $\mathrm{Ag}^{0}$ nanoparticles. The synthesis of AgNPs was confirmed by the change in color and the analysis of UV-vis absorption spectra.

been presented in other studies. ${ }^{\mathbf{1 1 , 2 1 , 2 2}}$ The functional groups in AgNPs were characterized by the FTIR spectra, while revealed peaks at 3385, 2925, 1732, 1645, 1556, 1359, 1079 and $537 \mathrm{~m}^{-1}$ (Fig. 3B). The peaks at 3385 and $2925 \mathrm{~cm}^{-1}$ may be due to $-\mathrm{OH}$ stretching from polysaccharides ${ }^{23}$ and $\mathrm{C}-\mathrm{H}$ stretching of alkanes, ${ }^{24}$ respectively. The peaks at 1732 and $1645 \mathrm{~cm}^{-1}$ could be denoted by the carbonyl stretching vibration, ${ }^{25}$ while the peaks at 1556 and $1359 \mathrm{~cm}^{-1}$ can be
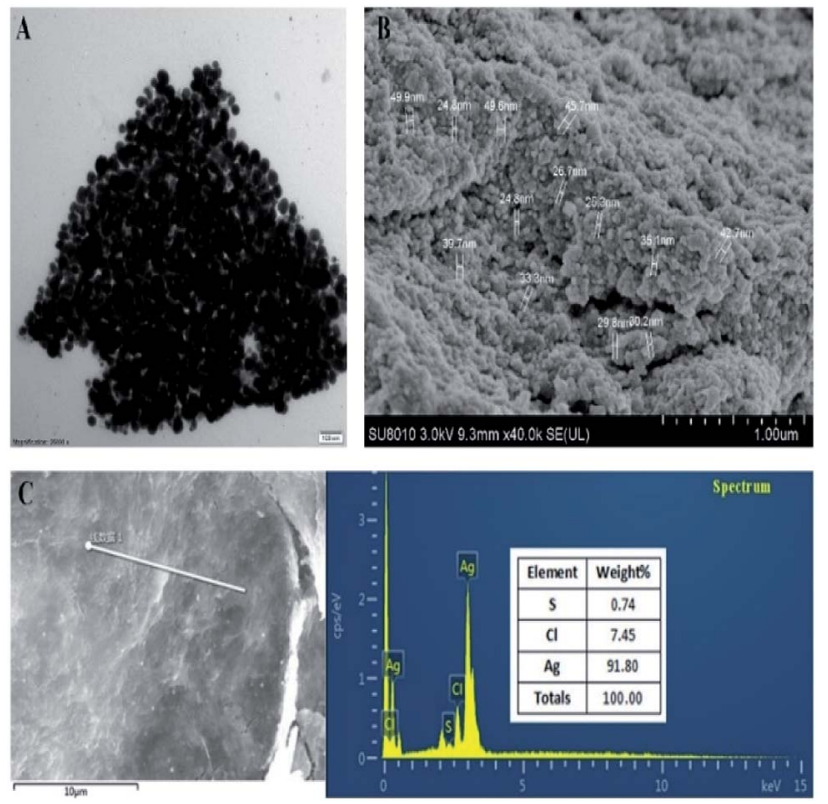

Fig. 2 Characterization of the biosynthesized AgNPs by the analysis of (A): transmission electron micrographs; (B): scan electron micrographs; (C): EDS profile. 
assigned to $(\mathrm{C}-\mathrm{N})$ and $(\mathrm{C}-\mathrm{C})$ stretching vibration of aromatic and aliphatic amines, respectively. The peaks at 1079 and $537 \mathrm{~cm}^{-1}$ could be assigned to $(\mathrm{C}-\mathrm{O})$ of an alkoxy group ${ }^{26}$ and the $\mathrm{CH}_{2}$ groups, ${ }^{23}$ respectively.

\subsection{In vitro antibacterial activity and mechanism}

The results of this study showed that the biosynthesized AgNPs at different concentrations of 5, 10, 15 and $20 \mu \mathrm{g} \mathrm{mL}{ }^{-1}$ had strong antibacterial activity against Xoo strain LND0005 and Ao strain RS-1 and the inhibitory effect increased with the increase of its concentration. In the presence of AgNPs at $20 \mu \mathrm{g} \mathrm{mL}^{-1}$, the diameter of the inhibition zones was $17.3 \mathrm{~mm}$ and $16.0 \mathrm{~mm}$ for Xoo strain LND0005 and Ao strain RS-1, respectively (Fig. 4). In agreement with our results, previous studies indicated that the AgNPs was able to suppress many bacterial plant diseases, such as Pseudomonas syringae pv. tomato DC $3000,{ }^{27}$ Clavibacter michiganensis subspecies michiganensis, ${ }^{28}$ Ralstonia solanacearum $^{29}$ and PEC-AgNPs and SDS-AgNPs were able to inhibit Dickeya spp. and Pectobacterium spp. ${ }^{30}$
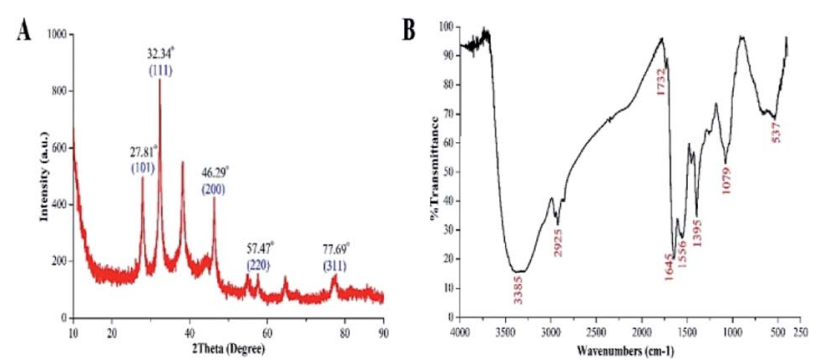

Fig. 3 Characterization of the biosynthesized AgNPs by the analysis of (A): XRD spectra and (B): Fourier transform infrared spectra.
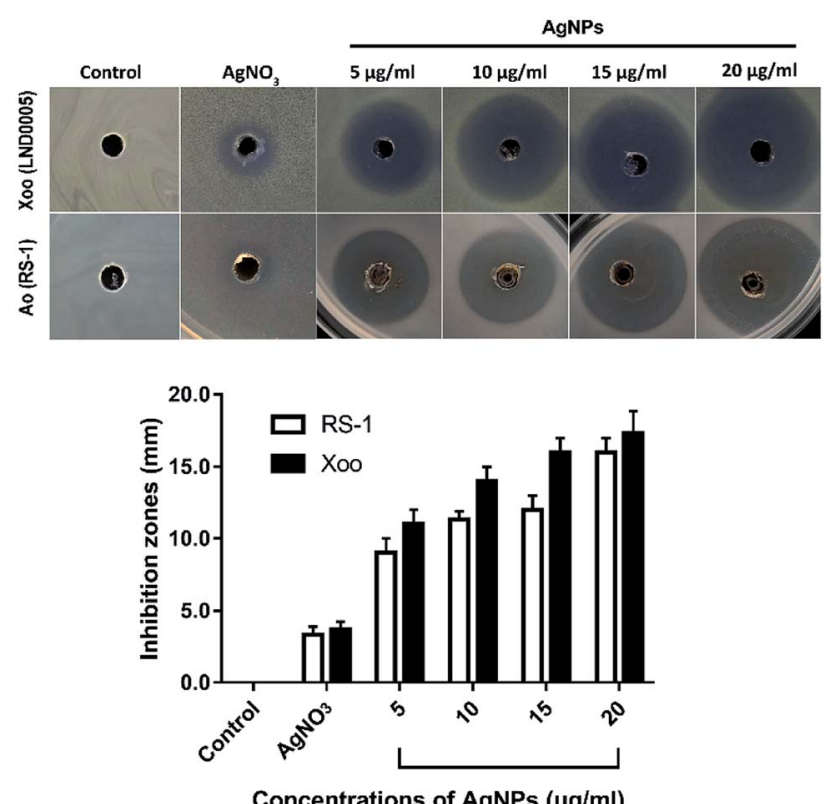

Fig. 4 Antibacterial activity of the biosynthesized AgNPs against Xoo strain LND0005 and Ao strain RS-1.
The results of this study also indicated that AgNPs significantly inhibited the growth of two main rice pathogenic bacteria after $48 \mathrm{~h}$ of incubation. Indeed, AgNPs at the concentrations of $5,10,15$, and $20 \mu \mathrm{g} \mathrm{mL}{ }^{-1}$ caused an 18.65, 72.29, 81.23 and $81.53 \%$ reduction in the OD600 value of Xoo strain LND0005, respectively, and $75.00,90.88,92.45$ and $92.65 \%$ reduction in the OD600 value of Ao strain RS-1, respectively (Fig. 5). The MICs of AgNPs to inhibit the growth of Xoo strain LND0005 and Ao were $10 \mu \mathrm{g} \mathrm{mL}^{-1}$. In agreement with previous reports., ${ }^{3,431}$ The results of this study also showed that the inhibitory effect in bacterial growth was highly related to the concentrations of AgNPs.

Results from this study indicated that biofilm formation and the swimming motility were significantly reduced by all the concentrations of the AgNPs in this study. Indeed, the AgNPs at the concentration of $20 \mu \mathrm{g} \mathrm{mL}{ }^{-1}$ caused an 86.31 and $80.59 \%$ reduction in OD570 value of Xoo strain LND0005 and Ao strain RS-1, respectively (Fig. 6). The results also indicated that Xoo strain LND0005 and Ao strain RS-1 were able to swim on the soft LB agar $(0.4 \%)$ medium with colony diameters of $21 \mathrm{~mm}$ and 20 $\mathrm{mm}$, respectively, after $24 \mathrm{~h}$ of incubation. However, AgNPs at $20 \mu \mathrm{g} \mathrm{mL} \mathrm{mL}^{-1}$ resulted in $70 \%$ and $80 \%$ reduction in colony diameters of Xoo strain LND0005 and Ao strain RS-1, respectively (Fig. 7). As previously reported, biofilm formation plays a vital role in protecting bacteria from external influences and keeping them alive, while the swimming motility allows the plant pathogenic bacteria to efficiently invade and colonize in host plants.,32,33 Therefore, the antibacterial activity of the AgNPs may be at least partially attributed to its inhibition on bacterial biofilm formation and the swimming motility.

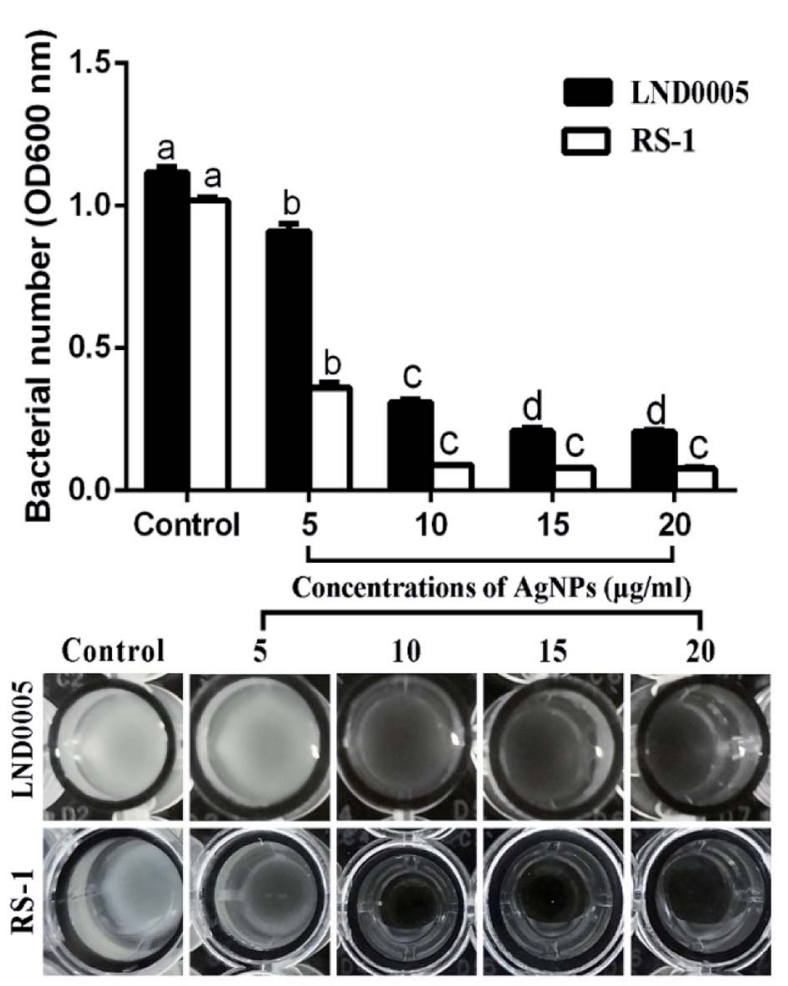

Fig. 5 Effect of biosynthesized AgNPs on the growth of Xoo strain LND0005 and Ao strain RS-1. 

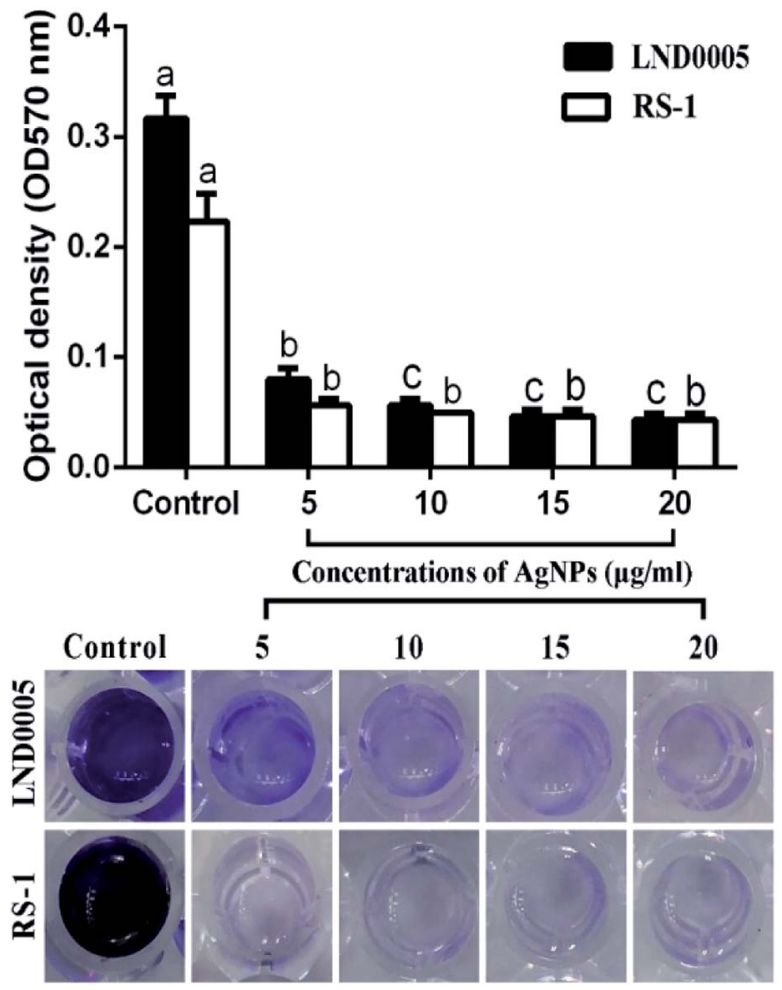

Fig. 6 Effect of the biosynthesized AgNPs on biofilm formation of Xoo strain LND0005 and Ao strain RS-1.
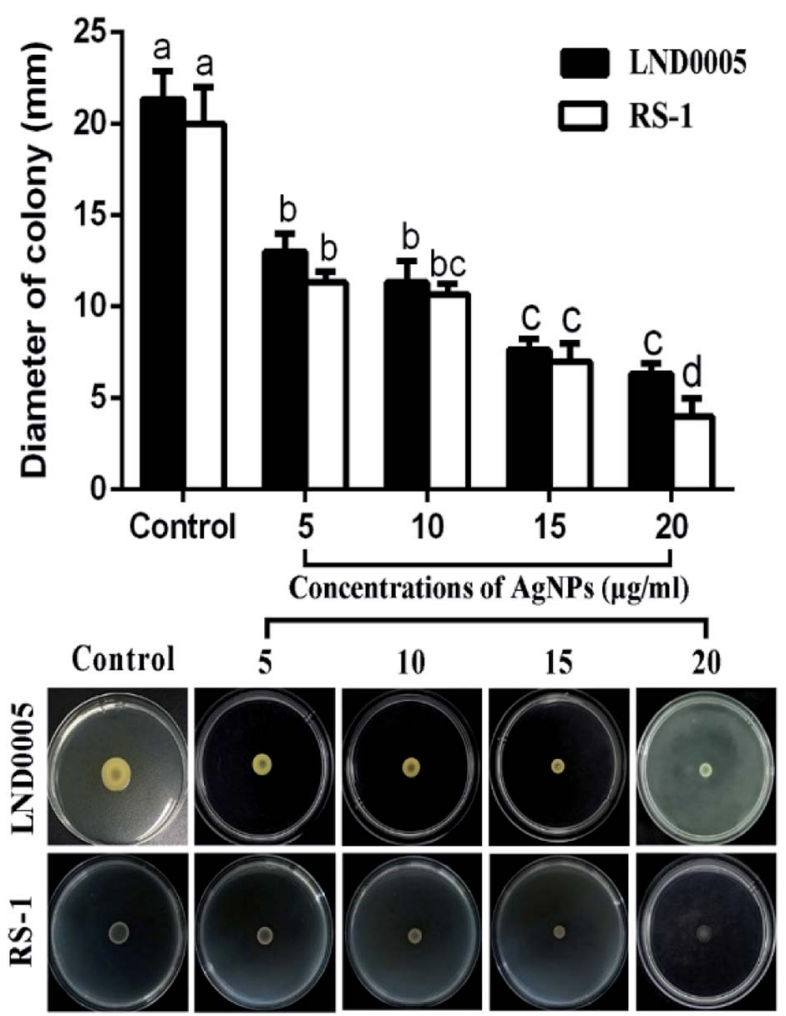

Fig. 7 Effect of the biosynthesized AgNPs on the swimming motility of Xoo strain LND0005 and Ao strain RS-1.
The results from TEM observation indicated that cell walls were intact in Xoo strain LND0005 and Ao strain RS-1 in the absence by the biosynthesized AgNPs. However, cell walls of Xoo strain LND0005 and Ao strain RS-1 were severely damaged in the presence of the biosynthesized AgNPs (Fig. 8). A bacteria cell wall is an essential structure for the life of bacteria, through the preservation of any environmental influences harmful to their lives. ${ }^{34,35}$ In addition, damage to cell walls was able to cause the loss of DNA and proteins, resulting in bacterial death.

\subsection{Plant growth promotion}

The results of this study indicated that the biosynthesized AgNPs significantly promoted the growth of rice seedlings compared to the control. The effects of silver nanoparticles on root length, shoot lengths, fresh weight and dry weight of rice were recorded in Fig. 9. The root length, shoot length, fresh weight and dry weight of rice seedlings which were treated with AgNPs were about $7.4 \mathrm{~cm}, 11.6 \mathrm{~cm}, 0.24 \mathrm{~g}$, and $0.04 \mathrm{~g}$, respectively, while the root length, shoot length, fresh weight and dry weight of rice seedlings treated with water were about $5.1 \mathrm{~cm}, 6.5 \mathrm{~cm}, 0.12 \mathrm{~g}$ and $0.03 \mathrm{~g}$, respectively. In agreement with the result of this study, some previous studies have reported the positive effect of nanoparticles on the plant growth. For example, Liang et al. ${ }^{36}$ reported that the Cos-La nanoparticles significantly enhanced the growth of rice plants by increasing the root length and fresh weight in hydroponics experiments. Byczyńska et $a l .{ }^{37}$ found that the silver nanoparticles stimulated tulips plants growth by increasing leaf greenness index, stomatal conductance, fresh root weight and root length. Venkatachalam et al. ${ }^{38}$ showed that the zinc oxide nanoparticles were involved in growth promotion of cotton plants.
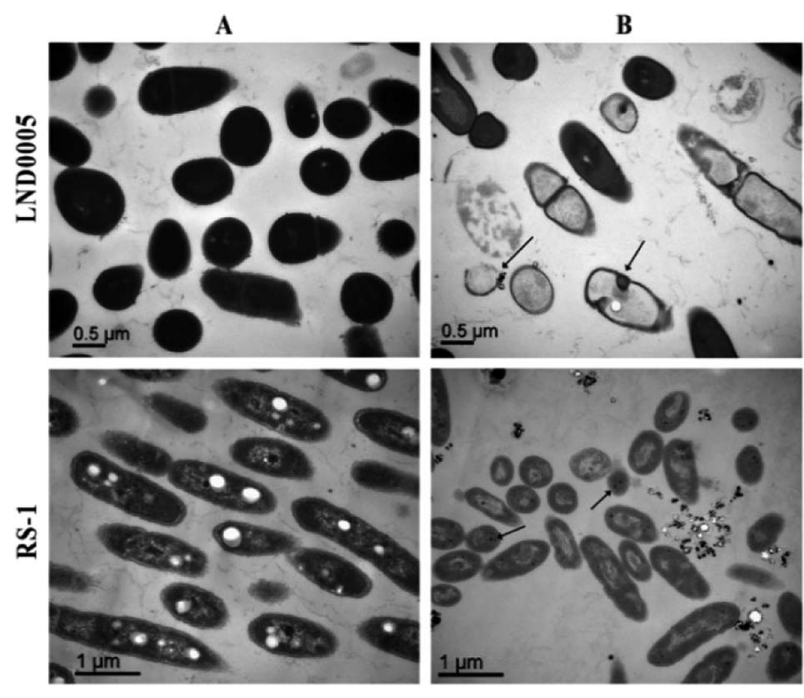

Fig. 8 TEM images of Xoo strain LND0005 and Ao strain RS-1 treated with distilled water (A); and treatment with $10 \mu \mathrm{g} \mathrm{mL} \mathrm{L}^{-1}$ of biosynthesized AgNPs (B). 

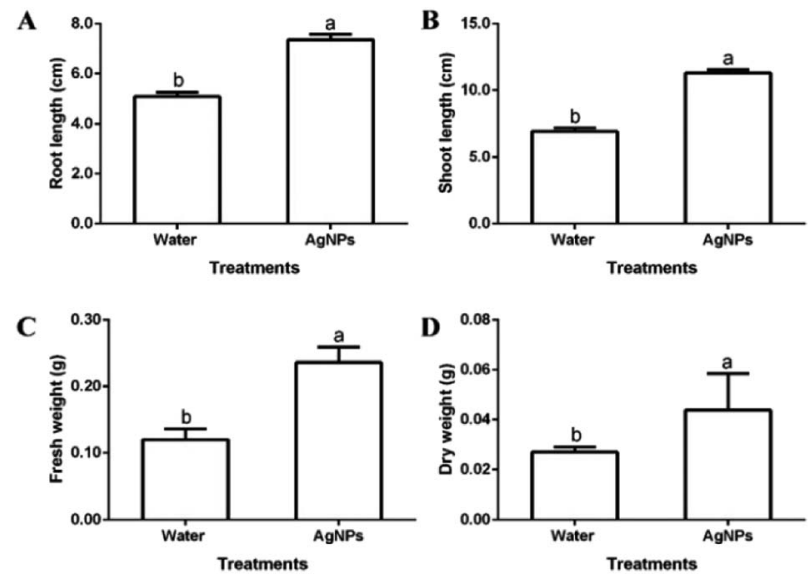

Fig. 9 Effect of the biosynthesized AgNPs on the growth of rice seedlings (A): root length; (B): shoot length; (C): fresh weight; (D): dry weight.

\section{Conclusions}

In this study, the AgNPs were successfully biosynthesized using endophytic bacteria isolated from medicinal plants $C$. sativum. The biosynthesized AgNPs was further confirmed and characterized by analysis of UV-visible spectroscopy, FTIR, XRD, SEM, TEM and EDS. Bacteriological test showed that the biosynthesized AgNPs had strong in vitro antibacterial activity against rice pathogenic bacteria Xoo strain LND0005 and Ao strain RS-1. Antibacterial activity of the biosynthesized AgNPs may be at least partially attributed to their inhibition on bacterial growth, biofilm formation and swimming motility. Overall, this study indicated that the new biosynthesized AgNPs had great potential in protecting rice plants from infection of bacterial leaf blight and bacterial brown stripe and plant growth promotion.

\section{Conflicts of interest}

The authors declare no conflict of interest.

\section{Acknowledgements}

This research was funded by the National Natural Science Foundation of China (31872017, 31571971, 31371904, 31801787), Zhejiang Provincial Project (2017C02002; 2019C02006), National Key Research and Development Program of China (2017YFD0201104), Shanghai Agricultural Basic Research Project (2014:7-3-1), the Fundamental Research Funds for the Central Universities, Dabeinong Funds for Discipline Development and Talent Training in Zhejiang University, and Key Subject Construction Program of Zhejiang for Modern Agricultural Biotechnology and Crop Disease Control.

\section{References}

1 S. Karmakar, K. A. Molla, K. Das, S. N. Sarkar, S. K. Datta and K. Datta, Sci. Rep., 2017, 7, 7900.
2 M. M. I. Masum, L. Liu, M. Yang, M. M. Hossain, M. M. Siddiqa, M. E. Supty, S. O. Ogunyemi, A. Hossain, Q. An and B. Li, J. Appl. Microbiol., 2018, 125, 1852-1867.

3 S. O. Ogunyemi, Y. Abdallah, M. Zhang, H. Fouad, X. Hong, E. Ibrahim, M. M. I. Masum, A. Hossain, J. Mo and B. Li, Artif. Cells, Nanomed., Biotechnol., 2019, 47, 341-352.

4 Y. Abdallah, S. O. Ogunyemi, A. Abdelazez, M. Zhang, X. Hong, E. Ibrahim, A. Hossain, H. Fouad, B. Li and J. Chen, BioMed Res. Int., 2019, 2019, 5620989.

5 Y. Abdallah, M. Yang, M. Zhang, M. M. I. Masum, S. O. Ogunyemi, A. Hossain, Q. An, C. Yan and B. Li, Lett. Appl. Microbiol., 2019, 68, 423-429.

6 S. Liu, L. Wei, L. Hao, N. Fang, M. W. Chang, R. Xu, Y. Yang and Y. Chen, ACS Nano, 2009, 3, 3891-3902.

7 K. Lamsa, S.-W. Kim, J. H. Jung, Y. S. Kim, K. S. Kim and Y. S. Lee, Mycobiology, 2011, 39, 26-32.

8 V. T. Nguyen, K. V. Q. Tran and Q. N. Tran, Arch. Phytopathol. Plant Prot., 2018, 51, 227-240.

9 M. J. Kasprowicz, A. Gorczyca and A. Szymocha, Biocontrol Sci. Technol., 2015, 25, 873-887.

10 V. K. Sharma, R. A. Yngard and Y. Lin, Adv. Colloid Interface Sci., 2009, 145, 83-96.

11 H. Fouad, L. Hongjie, D. Yanmei, Y. Baoting, A. El-Shakh, G. Abbas and M. Jianchu, Artif. Cells, Nanomed., Biotechnol., 2017, 45, 1369-1378.

12 A. S. Elshakh, S. I. Anjum, W. Qiu, A. A. Almoneafy, W. Li, Z. Yang, Z. Q. Cui, B. Li, G. C. Sun and G. L. Xie, J. Phytopathol., 2016, 164, 534-546.

13 R. Nijland, M. J. Hall and J. G. Burgess, PLoS One, 2010, 5, e15668.

14 S. Verma, K. Kingsley, M. Bergen, K. Kowalski and J. White, Microorganisms, 2018, 6, 21.

15 C. Ramteke, T. Chakrabarti, B. K. Sarangi and R. A. Pandey, J. Chem., 2012, 2013, 278925.

16 T. Singh, K. Jyoti, A. Patnaik, A. Singh, R. Chauhan and S. Chandel, J. Genet. Eng. Biotechnol., 2017, 15, 31-39.

17 M. A. Abbassy, M. A. Abdel-Rasoul, A. M. Nassar and B. S. Soliman, Arch. Phytopathol. Plant Prot., 2017, 50, 909926.

18 H. Lallawmawma, G. Sathishkumar, S. Sarathbabu, S. Ghatak, S. Sivaramakrishnan, G. Gurusubramanian and N. S. Kumar, Environ. Sci. Pollut. Res., 2015, 22, 17753-17768.

19 G. Suganya, S. Karthi and M. S. Shivakumar, Parasitol. Res., 2014, 113, 875-880.

20 H. Fouad, L. Hongjie, D. Hosni, J. Wei, G. Abbas, H. Ga'al and M. Jianchu, Artif. Cells, Nanomed., Biotechnol., 2018, 46, 558-567.

21 R. Manikandan, M. Beulaja, R. Thiagarajan, S. Palanisamy, G. Goutham, A. Koodalingam, N. Prabhu, E. Kannapiran, M. J. Basu and C. Arulvasu, Process Biochem., 2017, 55, 172-181.

22 W. M. Mahmoud, T. S. Abdelmoneim and A. M. Elazzazy, Front. Microbiol., 2016, 7, 1746.

23 G. S. Kiran, A. Sabu and J. Selvin, J. Biotechnol., 2010, 148, 221-225.

24 C. Aarthi, M. Govindarajan, P. Rajaraman, N. S. Alharbi, S. Kadaikunnan, J. M. Khaled, R. A. Mothana, 
N. A. Siddiqui and G. Benelli, Environ. Sci. Pollut. Res., 2018, 25, 10317-10327.

25 G. Benelli, S. Kadaikunnan, N. S. Alharbi and M. Govindarajan, Environ. Sci. Pollut. Res., 2018, 25, 1022810242.

26 H. A. Ghramh, K. M. Al-Ghamdi, J. A. Mahyoub and E. H. Ibrahim, J. Asia-Pac. Entomol., 2018, 21, 205-210.

27 S. Marpu, S. S. Kolailat, D. Korir, B. L. Kamras, R. Chaturvedi, A. Joseph, C. M. Smith, M. C. Palma, J. Shah and M. A. Omary, J. Colloid Interface Sci., 2017, 507, 437-452.

28 R. R. Rivas-Cáceres, J. L. Stephano-Hornedo, J. Lugo, R. Vaca, P. Del Aguila, G. Yañez-Ocampo, M. E. Mora-Herrera, L. M. C. Díaz, M. Cipriano-Salazar and P. A. Alaba, Microb. Pathog., 2018, 115, 358-362.

29 J. Chen, S. Li, J. Luo, R. Wang and W. Ding, J. Nanomater., 2016, 1, 1-15.

30 A. Dzimitrowicz, A. Motyka, P. Jamroz, E. Lojkowska, W. Babinska, D. Terefinko, P. Pohl and W. Sledz, Materials, 2018, 11, 331 .
31 L. L. Duffy, M. J. Osmond-McLeod, J. Judy and T. King, Food Control, 2018, 92, 293-300.

32 L. Zhang, J. Xu, J. Xu, H. Zhang, L. He and J. Feng, Microb. Pathog., 2014, 74, 1-7.

33 A. A. Ahmad, A. Askora, T. Kawasaki, M. Fujie and T. Yamada, Front. Microbiol., 2014, 5, 321.

34 M. G. Pinho, M. Kjos and J. W. Veening, Nat. Rev. Microbiol., 2013, 11, 601.

35 E. D. Primo, L. H. Otero, F. Ruiz, S. Klinke and W. Giordano, Biochem. Mol. Biol. Educ., 2018, 46, 83-90.

36 W. Liang, A. Yu, G. Wang, F. Zheng, P. Hu, J. Jia and H. Xu, Carbohydr. Polym., 2018, 199, 437-444.

37 A. Byczyńska, A. Zawadzińska and P. Salachna, Acta Agric. Scand., Sect. B, 2019, 69, 250-256.

38 P. Venkatachalam, N. Priyanka, K. Manikandan, I. Ganeshbabu, P. Indiraarulselvi, N. Geetha, K. Muralikrishna, R. Bhattacharya, M. Tiwari and N. Sharma, Plant Physiol. Biochem., 2017, 110, 118-127. 